\title{
Kapabilitas dan Kepemimpinan Anies Baswedan dalam Penanganan Banjir Ja- karta di Detik.com dan Kompas.com
}

\author{
Kunti Puspitasari \\ Departemen Ilmu Komunikasi, Program Pascasarjana, Universitas Indonesia \\ Gedung IASTH Lt. 6, Kampus UI Salemba, Jl. Salemba Raya 4 Jakarta 10430 \\ Corresponding author: puspitakunti@gmail.com
}

\begin{abstract}
Flooding is a major issue in Jakarta, proven that by the beginning of 2020 until the end of February 2020 there have been six floods. The performance of the Governor of DKI Jakarta is often highlighted by the media, especially online media related to flood management. This research aims to analyze the framing of the capabilities and leadership of Jakarta Governor Anies Baswedan in dealing with flooding in Jakarta 2020. Research method in the form of analysis of syntagmatis discourse with framing analysis of Pan \& Kosicki on flood Detik.com and Kompas.com. The results of this Detik.com also framed Baswedan positively. Anies is framed as having good capability and leadership in dealing with flooding in Jakarta. Anies quickly responded and wanted to get off the field in dealing with the flooding. Anies also has visibility in the public eye through uploading his activities on social media in dealing with flooding. Kompas.com frame Anies Baswedan as a leader who lacks the capability to be unable to run a flood management program properly. Anies' leadership was framed negatively because some of the flood management policies he issued were inappropriate and seemed unwilling to listen to the complaints offlood-affected residents. This research contributes to the form of a proposed balanced policy for online media in framing the capabilities and leadership of public figures, both from the selection of news sources and the proportion of news. For readers to get a full picture to assess the leadership performance of public figures. Keywords: Framing; Journalistic; Leadership; Online Media; Personal Branding
\end{abstract}

\begin{abstract}
Abstrak
Banjir merupakan persoalan utama di Jakarta, terbukti pada awal tahun 2020 sampai akhir Februari 2020 telah terjadi enam kali banjir. Kinerja Gubernur DKI Jakarta sering disorot media, khususnya media online terkait penanganan banjir. Penelitian ini bertujuan menganalisis pembingkaian kapabilitas dan kepemimpinan Gubernur DKI Jakarta Anies Baswedan dalam menangani banjir di Jakarta 2020. Metode penelitian berupa analisis wacana sintagmatis dengan analisis framing Pan \& Kosicki pada pemberitaan banjir di Detik.com dan Kompas.com. Hasil penelitian ini Detik.com membingkai Anies Baswedan secara positif. Anies dibingkai memiliki kapabilitas dan kepemimpinan yang baik dalam menangani banjir di Jakarta Anies cepat tanggap dan mau turun lapangan dalam menangani banjir. Anies juga memiliki visibilitas di mata publik melalui unggahan aktivitasnya di media sosial dalam menangani banjir. Kompas.com membingkai Anies Baswedan sebagai sosok pemimpin yang tidak memiliki kapabilitas karena tidak mampu menjalankan program penanganan banjir dengan baik. Kepemimpinan Anies dibingkai secara negatif karena sejumlah kebijakan penanganan banjir yang dikeluarkannya tidak tepat serta seakan tidak mau mendengarkan keluhan warga terdampak banjir. Penelitian ini memberikan kontribusi berupa usulan kebijakan keberimbangan bagi media online dalam membingkai kapabilitas dan kepemimpinan tokoh publik, baik dari pemilihan sumber berita maupun proporsi pemberitaan. Bagi pembaca agar memperoleh gambaran utuh untuk menilai performa kepemimpinan tokoh publik. Kata kunci: Framing; Jurnalistik; Kepemimpinan; Media Online; Personal Branding
\end{abstract}

\section{Pendahuluan}

Banjir pada awal tahun 2020 di wilayah Jakarta dan sekitarnya menjadi salah satu peristiwa yang menyorot kinerja Anies Baswedan sebagai Gubernur DKI Jakarta. Kurun waktu Januari-Februari 2020, kawasan DKI Jakarta sudah enam kali direndam banjir dengan luas wilayah yang signifikan (Lova \& Maullana, 2020). Banjir menjadi salah satu permasalahan di DKI Jakarta yang tidak habis dibahas. Persoalan banjir menjadi tolok ukur keberhasilan kinerja gubernur dari masa ke masa, tidak terkecuali ketika masa pemerintahan Anies Baswedan sebagai Gubernur DKI Jakarta. 
Kuantitas banjir di Jakarta yang terjadi di awal tahun 2020 membuat nama Gubernur DKI Jakarta, Anies Baswedan ramai diperbincangkan masyarakat bahkan sempat menjadi trending topic di media sosial. Salah satunya tanda pagar (tagar) \#WajahBaruJakarta yang menjadi bagian unggahan Anies di Twitter seketika menjadi trending topic ketika banjir melanda Jakarta pada 23 Februari 2020. Tagar tersebut menjadi sebuah sindiran bagi Anies atas peristiwa banjir yang terus-menerus terjadi di wilayah Jakarta. Berbagai media ramai memberitakan peristiwa tersebut. Banjir di Jakarta tergolong berita bencana yang menarik karena semakin besar peristiwa bencana terjadi, semakin besar pula dampak yang ditimbulkan Pinontoan \& Wahid (2020).

Media online menjadi yang tercepat memberitakan banjir Jakarta karena media online menekankan pada kecepatan dan pembaruan segera (Lee et al., 2014). Dalam mengejar kecepatan, tidak jarang wartawan media online menggunakan media rujukan lainnya sebagai sumber berita, salah satunya media sosial seorang tokoh atau organisasi tertentu. Dalam pemberitaan banjir Jakarta, media online kerap menjadikan akun media sosial Anies sebagai sumber informasi, seperti memantau kegiatan Anies sebagai Gubernur DKI Jakarta dan perkembangan kondisi terkini wilayah yang terdampak banjir.

Media turut mengaitkan berita banjir dengan sosok dan kinerja Anies Baswedan sebagai Gubernur DKI Jakarta. Tidak bisa dipungkiri bahwa gerak gerik politisi, termasuk kepala daerah, menjadi daya tarik pemberitaan media. Khususnya pada pemberitaan di media online, jika diamati secara makro, media online cenderung menyiarkan ragam berita tentang selebritas dunia hiburan dan politik yang menekankan pada karakter dan aspek personal kehidupan (Lestari, 2017). Cara media online membingkai berita sangat menentukan persepsi dan opini publik yang tercipta tentang sosok Anies Baswedan sebagai Gubernur DKI Jakarta.
Pembingkaian berita (framing) pada dasarnya adalah metode untuk melihat cara bercerita media atas peristiwa. Cara bercerita tersebut tergambar pada "cara melihat" terhadap realitas yang dijadikan berita yang berpengaruh pada hasil akhir dari konstruksi realitas (Eriyanto, 2002). Dalam menyampaikan berita, masing-masing media melakukan pembingkaian atau framing yang berbeda satu dengan lainnya. Eriyanto (2002) menyatakan bahwa perbedaan pembingkaian yang berbeda antarmedia terjadi karena sebuah peristiwa dimaknai dan dikonstruksi secara berbeda oleh media. Hal ini tidak luput dari dua esensi utama dalam framing, yaitu bagaimana peristiwa dimaknai (berhubungan dengan bagian mana yang diliput dan mana yang tidak diliput) dan bagaimana fakta ditulis (berhubungan dengan pemakaian kata, kalimat, dan gambar untuk mendukung gagasan).

Banyak hal yang memengaruhi perbedaan penyajian berita dalam media massa ke masyarakat, yaitu wartawan sebagai orang pertama dalam produksi berita, serta jajaran redaksi dan pemilik modal yang memiliki kuasa penuh terhadap media itu (Adhiarso et al., 2017). Perbedaan pembingkaian terlihat pada hasil penelitian Adzhani \& Ginting (2018) tentang pembingkaian pemberitaan pidato pelantikan Anies Baswedan sebagai Gubernur DKI Jakarta di Viva.co.id dan Detik.com. Viva.co.id membingkai Anies menjadi sosok yang patut dipersalahkan karena menyinggung pihak tertentu dengan menggunakan kata "pribumi" dalam pidatonya. Detik.com membingkai penggunaan kata "pribumi" di pidato Anies bukan hal yang salah karena konteks pidato terkait penjajahan. Penelitian Pinontoan \& Wahid (2020) juga menghasilkan perbedaan pembingkaian pemberitaan banjir Jakarta pada Januari 2020 di Kompas.com dan Jawapos.com. Pada pembingkaian Kompas. com, pembaca diarahkan untuk menuntut, mempertanyakan, dan menggugat ketidakberdayaan pemerintah pusat dalam menangani banjir Jakarta Januari 2020. Pembingkaian berita banjir oleh 
Jawapos.com cenderung mengarah pada pemberian citra baik pada kinerja pemerintah daerah. Jawapos.com menggunakan frame personalisasi yang lebih dominan dalam pemberitaan melalui pemilihan sumber berita, yaitu Gubernur DKI. Personalisasi tokoh publik, seperti pejabat negara dan politisi, menjadi subjek yang banyak diteliti. Riyantini \& Sarwititi (2018) menganalisis perbandingan antara Naskah Pidato Kenegaraan Presiden Joko Widodo Tahun 2016 dengan Tahun 2017 berdasarkan perspektif komunikasi politik dan komunikasi pembangunan. Naskah pidato Presiden tahun 2017 lebih banyak bernuansa komunikasi politik didukung dengan sajian data keberhasilan pembangunan dibandingkan dengan tahun 2016. Sebagai seorang pemimpin negara, gaya komunikasi Presiden menjadi sorotan utama seluruh tokoh serta pengamat politik, sehingga menjadi salah satu fenomena yang menarik untuk diteliti.

Penelitian Azhar \& Pekuwali (2018) dan Srisadono (2018) menganalisis personal branding para kandidat pemimpin daerah dari dua sisi berbeda. Srisadono (2018) menganalisis dari sisi para calon pemimpin daerah, yaitu Calon Gubernur dan Wakil Gubernur Jawa Barat 2018 dalam membentuk personal branding di media sosial Twitter. Personal branding merupakan kegiatan yang ditujukan untuk mengelola brand orang-perorangan yang dapat memengaruhi persepsi orang lain terhadapnya (Astuti, 2016). Personal branding para calon pemimpin daerah Jawa Barat 2018 di Twitter pada penelitian Srisadono (2018) mengarah pada delapan konsep utama personal branding yang dikemukakan Montoya, yaitu the law of specialization, the law of leadership, the law of personality, the law of distinctiveness, the law of visibility, the law of unity, the law of persistence, dan the law of goodwill. Melalui Twitter, para kandidat mampu membentuk personal branding untuk membangun opini publik dan memengaruhi pengikutnya di media sosial.
Azhar \& Pekuwali (2018) menganalisis tokoh publik dari konstruksi yang dilakukan media, yaitu bagaimana media online Medanbisnisdaily.com membingkai sosok Edy Rahmayadi, salah satu calon Gubernur Sumatra Utara 2018. Pada tahap konstruksi pemberitaan, Medanbisnisdaily.com lebih menekankan pada karakter atau citra Edy Rahmayadi yang negatif. Medanbisnisdaily.com menempatkan event sebagai tema marjinal dan digunakan sebagai pembuka berita yang menggambarkan karakter atau citra Edy Rahmayadi.

Pemberitaan terkait pemimpin daerah menjadi daya tarik tersendiri bagi media. Azhar \& Pekuwali (2018) menyatakan media berperan dalam membangun citra tertentu dari tokoh politik karena peran media dalam mengonstruksi realitas. Media massa bisa mengangkat seseorang menjadi tenar dan didukung oleh masyarakat, tetapi juga dapat menurunkan orang tersebut menjadi sosok yang paling dibenci. Temuan pada penelitian Pinontoan \& Wahid (2020) yang memperlihatkan adanya pembingkaian personalisasi pada sosok Gubernur DKI Jakarta di tengah permasalahan banjir yang diangkat membuat penelitian ini ingin mengeksplorasi dengan berfokus pada pembingkaian personalisasi Gubernur DKI Jakarta di media online. Analisis dilakukan di dua media online, yaitu Kompas.com dan Detik. com. Berdasarkan penelitian sebelumnya oleh Adzhani \& Ginting (2018) dan Pinontoan \& Wahid (2020), Detik.com dan Kompas.com memperlihatkan pembingkaian yang berseberangan dalam memberitakan persoalan ibu kota Jakarta dan sosok Gubernur DKI Jakarta, Anies Baswedan. Hal ini terkait personal branding Anies.

\section{Personal Branding}

Branding adalah proses memberikan produk dan layanan dengan kekuatan merek, sehingga membuat perbedaan antara produk yang satu dengan yang lainnya. Konsep branding juga termasuk pada kepribadian atau karakter (asosiasi tak berwujud yang membantu membangun nada un- 
tuk kata-kata dan tindakan untuk merek) (Kotler \& Keller, 2016). Personal branding sangat penting bagi seseorang dalam menempuh perjalanan kariernya, termasuk bagi seorang tokoh publik (public figure). Berbagai cara dilakukan untuk memperlihatkan kualitas dan nilai yang dimilikinya kepada publik. Posisi sebagai Gubernur DKI Jakarta merupakan jabatan politis. Seorang politisi diperlakukan sebagai merek yang menarik perhatian dalam studi komunikasi politik. Seorang manusia dipandang sebagai merek politik, harus ada pertimbangan untuk mengombinasikan karakteristik yang unik bagi kandidat pada saat itu. Sebuah candidate brand adalah citra publik politisi yang terbentuk dari keseluruhan impresi komunikasi dari masyarakat (Marland, 2013).

Montoya (2002) dalam Wilson (2003), mengungkapkan delapan konsep utama dalam membangun personal branding, yaitu the law of specialization, the law of leadership, the law of personality, the law of distinctiveness, the law of visibility, the law of unity, the law of persistence, dan the law of goodwill. The law of specialization terkait spesialisasi seseorang di suatu bidang. The law of leadership melihat cara seseorang menyampaikan otoritasnya pada orang lain, apakah dengan keunggulan yang dimilikinya, penggunaan posisi atau popularitasnya. Bagaimana akhirnya seseorang merealisasikan janji dan mempromosikan hasil yang dibangun. The law of personality terkait bagaimana seseorang apa adanya, karena orang-orang tidak menyukai individu yang mencoba memproyeksikan diri mereka sebagai orang yang 'bersih', tetapi lebih disukai yang 'nyata'. Publik menyukai seseorang yang dapat mengambil risiko. The law of distinctiveness tentang bagaimana mengekspresikan diri dengan cara yang berbeda untuk menciptakan kesan yang kuat. The law of visibility adalah bagaimana personal branding harus dilihat secara konsisten dan berulang kali. Penting untuk mempromosikan diri dan memanfaatkan peluang. The law of unity tentang bagaimana seseorang menjalani kehidupan pribadi sesuai dengan kepribadian publiknya. The law of persistence, kegigihan dibutuhkan untuk mencapai personal branding. The law of goodwill, niat baik menciptakan personal branding yang baik di tengah publik, hal ini terkait dengan kepemimpinan.

\section{Teori Kepemimpinan Transaksional dan Transformasional}

Hackman \& Johnson menjelaskan kepemimpinan adalah komunikasi manusiawi (simbolik) yang memodifikasi sikap dan perilaku orang lain untuk memenuhi tujuan kelompok dan kebutuhan bersama (Liu et al., 2020). Pendekatan relasional yang menekankan pada peran komunikasi dalam kepemimpinan diwujudkan dalam teori kepemimpinan transformasional. Teori ini dikemukakan oleh Bums (1978) dan dikembangkan lebih lanjut sekaligus dioperasionalkan oleh Bass tahun 1985. Kepemimpinan transformasional menyoroti cara para pemimpin mengamankan tingkat kepercayaan pengikut yang luar biasa dan menginspirasi pengikut untuk meniru perilaku mereka (Gardner, 2003). Model kepemimpinan transformasional membuat perbedaan dengan pemimpin transaksional. Kepemimpinan transaksional mengacu pada hubungan pertukaran di antara para pemimpin dan pengikut. Pemimpin transaksional terkait dengan pemenuhan harapan kepentingan diri sendiri dan kebutuhan jajarannya. Pemimpin yang gagal untuk memenuhi hal tersebut kehilangan reputasi dan tidak dianggap sebagai pemimpin yang efektif (Bass, 1985).

Gardner (2003) berpendapat bahwa inti dari kepemimpinan transformasional adalah konsep keteladanan. Artinya, pemimpin yang ingin menanamkan cita-cita kerja keras dan perilaku etis melakukannya dengan mencontohkan cita-cita tersebut melalui perilaku mereka sendiri. Kata-kata dan perbuatan sangat penting untuk pemimpin transformasional. Pemimpin transformasional menciptakan hubungan antara pemimpin dan pengikut yang membantu pengikut mencapai potensi penuh dan memiliki potensi untuk mengubah pemimpin dan pengi- 
kut melalui proses komunikasi. Bass (1985) menyebutkan tiga faktor yang berhubungan dengan kepemimpinan transformasional, yaitu: (1) kepemimpinan karismatik (pemimpin membangkitkan antusiasme, keyakinan, kesetiaan, kebanggaan, dan kepercayaan pada diri sendiri dan tujuan individu); (2) pertimbangan individual (pemimpin mempertahankan pengembangan dan orientasi individualistik terhadap jajarannya); dan (3) stimulasi intelektual (pemimpin meningkatkan kemampuan pemecahan masalah dari tim). Kepemimpinan yang disorot media online dapat dianalisis melalui jurnalisme online.

\section{Jurnalisme Online}

Kehadiran media online dalam dunia jurnalisme seiring dengan pesatnya perkembangan teknologi komunikasi dan pertumbuhan pengguna internet di Indonesia. Dibandingkan dengan media konvensional, media online jauh lebih unggul dalam hal kecepatan pemberitaan yang dapat diakses oleh penggunanya di mana saja dan kapan saja (Solihin \& Kurnia, 2017). Margianto \& Syaefullah (2012) menyebutkan masalah pokok dalam jurnalisme online adalah kualitas dan kredibilitas informasi yang sampai ke masyarakat. Hal ini terkait dengan karakteristik kecepatan menyampaikan informasi, sehingga acapkali lembaga berita online menyampaikan informasi yang belum final terverifikasi kepada masyarakat luas. Hal ini terkadang menimbulkan mispersepsi dan mis-interpretasi fakta. Berita di media online yang mengandalkan kecepatan kerap tidak lengkap dengan unsur 5W (what, who, why, when, where) $+1 \mathrm{H}$ (how) layaknya pakem jurnalistik. Hal lain yang disoroti dalam jurnalisme online adalah keberimbangan. Karakteristik media online yang memunculkan sebuah topik utama menjadi beberapa berita membuat keberimbangan biasanya tidak muncul pada berita pertama, tapi pada berita kedua, ketiga, dan selanjutnya.

Media berfungsi sebagai penyampai informasi kepada publik sekaligus membentuk opini publik tentang sebuah isu. Vreese (2005) men- gatakan salah satu cara media yang berpengaruh dalam membentuk opini publik adalah dengan membingkai peristiwa dan masalah (framing). Isu yang menyangkut kepentingan publik, seperti banjir, media dapat membingkai personal branding Gubernur DKI Jakarta, Anies Baswedan sebagai orang atau tokoh yang dianggap paling terkait dengan peristiwa banjir di wilayah tersebut. Penelitian ini melihat pembingkaian berita terkait banjir di Jakarta yang menampilkan sosok Gubernur DKI Jakarta di dua media online, yaitu Detik.com dan Kompas.com. Kedua media online ini merupakan pionir situs berita online di Indonesia dan memiliki kekhasan dalam penulisan beritanya. Selain itu, menurut Alexa.com tanggal 21 Februari 2020, kedua situs ini masuk ke dalam lima situs berita yang paling banyak pembacanya (Mastiyanto, 2020).

Detik.com hadir pada 9 Juli 1998. Digagas oleh Budiono Darsono, Yayan Sopyan, Abdul Rahman dan Didi Nugrahadi, Detik.com dianggap mengubah khasanah media online yang statis. Momen perubahan sosial politik di tahun 1998 menggerakkan pendirinya untuk membuat sebuah media baru yang tidak mudah dibredel dan mampu memberikan informasi secepat mungkin tanpa harus menunggu dicetak esok pagi. www. detik.com sebagai media online generasi pertama mengenalkan langgam berita baru, yaitu ringkas, to the point, serta running news, yakni penyajian berita serial yang meniru cara breaking news kantor berita asing (Margianto \& Syaefullah, 2012).

Kompas.com pertama kali hadir di internet pada 14 September 1995 dengan nama Kompas Online. Mulanya, Kompas Online diakses dengan alamat kompas.co.id yang hanya menampilkan replika berita-berita harian Kompas yang terbit dihari itu. Alamat Kompas Online berubah menjadi www.kompas.com dan menjadi unit bisnis tersendiri di bawah bendera PT Kompas Cyber Media (KCM) pada 6 Agustus 1998. Sejak saat itu, para pengunjung KCM juga mendapatkan update perkembangan berita-berita terbaru sepanjang hari. Pada 29 Mei 2008, portal berita 
ini melakukan rebranding dirin menjadi Kompas.com. Merujuk pada brand Kompas yang dikenal menghadirkan jurnalisme memberikan makna yang tidak terlepas dari framing media.

\section{Framing}

Framing menurut Borah (2011) adalah konsep penting dalam menjelaskan bagaimana konten media memengaruhi konsumennya (Burgers et al., 2016). Pengaturan bingkai mengacu pada interaksi antara bingkai media, pengetahuan awal, dan kecenderungan individu. Bingkai dalam berita dapat memengaruhi pembelajaran, penafsiran, serta evaluasi masalah dan peristiwa. Terkait penelitian ini, pembingkaian media dapat memengaruhi penafsiran publik tentang personal branding seseorang, terutama kapabilitas dan kepemimpinan tokoh publik.

Scheufele (1999) melihat pembingkaian dalam macrolevel dan microlevel construct. Sebagai makrokonstruksi, Shoemaker \& Reese (1996) menyatakan bahwa istilah framing mengacu pada mode presentasi yang digunakan jurnalis dan komunikator lain untuk menyajikan informasi dengan cara beresonansi dengan skema mendasar yang ada di antara audiens. Sebagai mikrokonstruksi, pembingkaian menjelaskan bagaimana orang menggunakan informasi dan fitur presentasi mengenai masalah saat mereka membentuk tayangan (Scheufele \& Tewskbury, 2007). Scheufele berpendapat bahwa teori pembingkaian dapat menjelaskan sejauh mana media memengaruhi pemahaman warga politik. Shah et al. menemukan paparan informasi yang tidak dikenal yang dibingkai mengarahkan individu untuk menyesuaikan keyakinan masyarakat pada topik tertentu yang menghasilkan kognisi lebih rinci. Ini menunjukkan pengetahuan politik memoderasi cara individu dapat memproses informasi yang dibingkai (Lecheler \& De Vreese, 2012).

Berdasarkan latar belakang dan tinjauan pustaka yang ada, penelitian ini menganalisis media online Detik.com dan Kompas.com membingkai kapabilitas dan kepemimpinan Anies
Baswedan sebagai Gubernur DKI Jakarta dalam menangani banjir di Jakarta. Pembingkaian secara berbeda oleh media online terhadap sosok Anies Baswedan sebagai Gubernur DKI Jakarta dalam menangani banjir menentukan sosok Anies sebagai pemimpin Jakarta dimaknai oleh masyarakat, khususnya pembaca media tersebut.

\section{Metode Penelitian}

Penelitian ini menggunakan pendekatan kualitatif dengan paradigma konstruktivisme. Paradigma konstruktivisme menganggap realitas sosial dilihat sebagai hasil konstruksi sosial sehingga kebenaran suatu realitas sosial bersifat relatif. Media menyusun realitas dari berbagai peristiwa yang terjadi hingga menjadi cerita yang bermakna (Yuzi et al., 2019). Teknik pengumpulan data dalam penelitian ini adalah analisis wacana sintagmatis, yang menganalisis wacana dengan metode kebahasaan (syntaxis approach), di mana peneliti mengeksplorasi kalimat demi kalimat untuk menarik kesimpulan (Hamad, 2007). Wacana yang digunakan adalah berita media online Kompas.com dan Detik.com terkait banjir Jakarta tanggal 23-24 Februari 2020. Metode analisis yang digunakan adalah analisis framing Zhongdang Pan dan Gerald M. Kosicki. Konsep framing menurut Pan \& Kosicki (1993) merupakan proses pembuatan suatu pesan lebih menonjol, menempatkan informasi lebih daripada yang lain sehingga khalayak lebih tertuju pada pesan tersebut.

Unit analisis dalam penelitian ini adalah berita tentang banjir Jakarta yang menampilkan sosok Gubernur DKI Jakarta, Anies Baswedan di Detik.com dan Kompas.com tanggal 23-24 Februari 2020. Daftar berita yang dianalisis tercantum pada Tabel 1 .

Tabel 1 menunjukkan daftar judul berita terkait banjir Jakarta dan sosok Anies Baswedan yang dimuat pada tanggal 23-24 Februari 2020 di Detik.com dan Kompas.com. Pemilihan tanggal tersebut karena banjir kembali terjadi untuk keenam kalinya di Jakarta pada 23 Februari 2020. 
Tabel 1. Daftar Berita yang Dianalisis

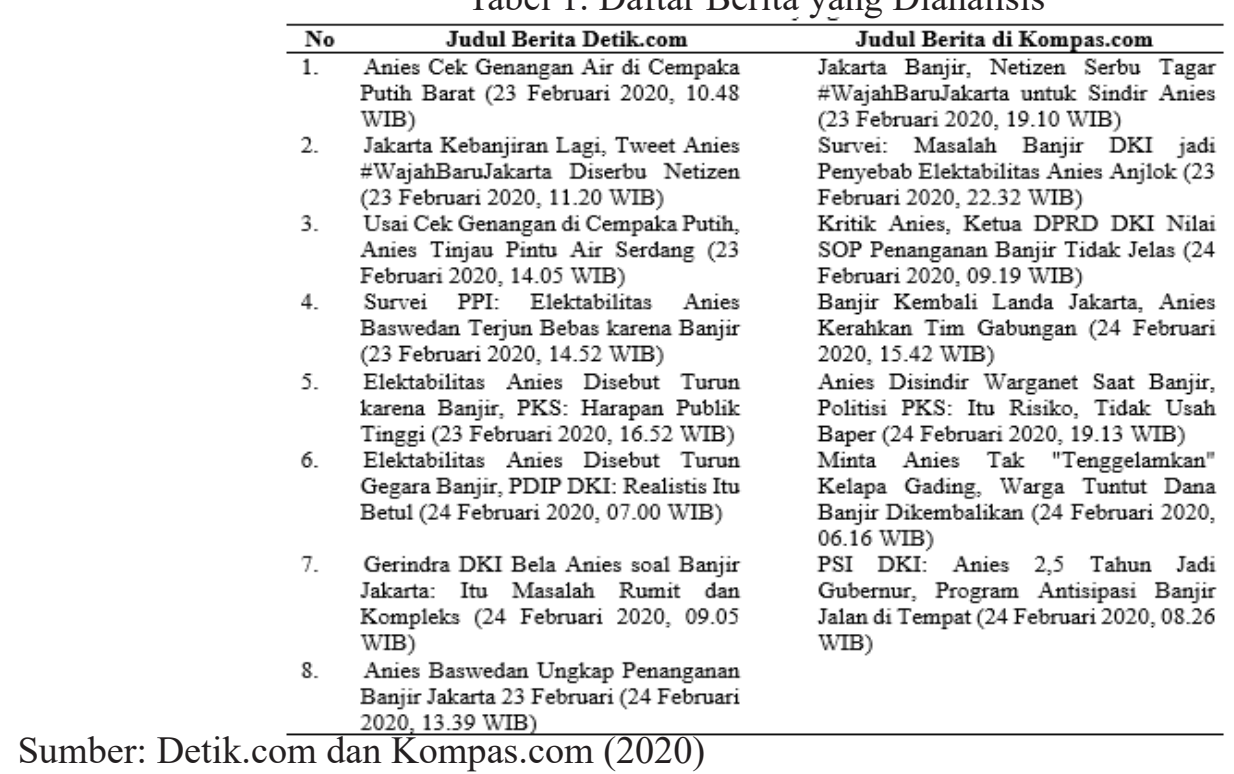

Sumber: Detik.com dan Kompas.com (2020)

Analisis data menggunakan perangkat framing Pan \& Kosicki (Eriyanto, 2002), dibagi menjadi empat struktur besar, yaitu struktur sintaksis, struktur skrip, struktur tematik, dan struktur retoris. Struktur sintaksis melihat bagaimana wartawan menyusun peristiwa (pernyataan, opini, kutipan, dan pengamatan) ke dalam susunan berita. Struktur yang diamati adalah lead berita, latar, headline, kutipan, dan sebagainya. Struktur skrip terkait bagaimana wartawan menceritakan peristiwa ke dalam bentuk berita. Versi asli struktur berita terdiri dari $5 \mathrm{~W}+1 \mathrm{H}$ dalam penulisan berita, yaitu siapa, apa, kapan, di mana, mengapa dan bagaimana (Pan \& Kosicki, 1993). Struktur tematik melihat bagaimana wartawan mengungkapkan pandangannya atas peristiwa ke dalam proposisi, kalimat, atau hubungan antarkalimat yang membentuk teks secara keseluruhan. Struktur retoris berkaitan dengan bagaimana wartawan menekankan arti tertentu ke dalam berita. Pilihan kata, idiom, grafik, dan gambar yang digunakan wartawan dalam berita bukan hanya untuk mendukung tulisan, namun juga menekankan arti tertentu kepada pembaca.

\section{Hasil Penelitian dan Pembahasan}

Berikuthasil analisis terhadap 15 berita (Tabel 1) menggunakan metode framing Pan \& Kosicki.

\section{Framing Sosok Gubernur DKI Jakarta di Detik.com}

Delapan berita di Detik.com (Tabel 1), sebagian besar berisi tentang elektabilitas Anies Baswedan menurut hasil survei Parameter Politik Indonesia (PPI) dan Politika Research and Consulting (PRC), tiga berita tentang penanganan banjir yang dilakukan Anies, dan satu berita tentang ramainya sindiran terhadap Anies di Twitter. Berdasar analisis perangkat framing Pan \& Kosick, empat struktur besar diuraikan berturut-turut yaitu struktur sintaksis, struktur skrip, struktur tematik, dan struktur retoris.

Komponen pertama, struktur sintaksis sebagai komponen pertama framing Pan \& Kosicki, kedelapan berita tersebut ditulis dengan struktur piramida terbalik, di mana wartawan menuliskan informasi paling penting di bagian atas tulisan, seterusnya hingga ke akhir sebagai informasi pendukung. Pada sebagian besar berita menggunakan informasi pendukung yang sama, khususnya yang bertema elektabilitas Anies menurut hasil survei PPI dan PRC. 
Kedelapan judul berita bertendensi netral, cenderung tidak menyudutkan pihak mana pun.

Kalimat pembuka di masing-masing berita langsung menunjukkan inti persoalan dalam berita, wartawan tidak menuliskan kata bombastis dalam mengawali berita. Jenis kalimat pembuka dari kedelapan berita tersebut sama dengan menggunakan kalimat tidak langsung. Latar belakang informasi ditampilkan di awal atau di paragraf terakhir sebagai informasi pendukung. Pada berita 2 (Tabel 1) berjudul "Jakarta Kebanjiran Lagi, Tweet Anies \#WajahBaruJakarta Diserbu Netizen", latar belakang informasi terdapat di paragraf awal untuk menunjukkan mengapa warganet menyerbu tweet Anies. Serbuan warganet dilatarbelakangi oleh tweet Anies sehari sebelum banjir (22 Februari 2020) yang memperlihatkan kondisi Jakarta yang indah dan nyaman dengan tagar \#WajahBaruJakarta. Ternyata keesokan harinya, Jakarta kembali dilanda banjir, sehingga warganet menyindir tweet Anies dengan mengunggah foto banjir Jakarta yang dilengkapi tagar \#WajahBaruJakarta. Latar belakang informasi yang ditempatkan di paragraf terakhir berita terkait respon beberapa politisi terhadap elektabilitas Anies yang turun akibat banjir berdasarkan hasil survei PPI dan PRC. I

Dalam menyajikan berita, wartawan Detik. com menampilkan kutipan narasumber. Kutipan yang berasal dari wawancara langsung hanya pada berita bertema hasil survei PPI dan PRC. Proporsi sumber berita dari berita tersebut diambil dari tiga partai yang mewakili dua dukungan politik. Partai Keadilan Sejahtera (PKS) dan Gerindra sebagai partai pengusung Anies di Pilgub DKI Jakarta 2017 lalu, serta PDI Perjuangan (PDIP) sebagai partai oposisi di pilgub kemarin. Pada berita bertema penanganan banjir, wartawan mengambil sumber dari media sosial Anies, Dinas Sumber Daya Air (SDA) DKI Jakarta, dan keterangan tertulis dari Kepala Badan Penanggulangan Bencana Daerah (BPBD) DKI Jakarta. Tidak ada wawancara yang dilakukan oleh wartawan untuk memeroleh informasi atau klarifikasi atas topik yang diangkat. Dalam berita 2 (Tabel 1) wartawan mencantumkan tweet pengamat politik Yanuarto Wijaya dan tweet seorang warganet @ Takviri yang keduanya memprotes dan menyindir tweet Anies bertagar \#WajahBaruJakarta.

Komponen kedua adalah struktur skrip. Dari kedelapan berita di Detik.com, semuanya mengandung $5 \mathrm{~W}+1 \mathrm{H}$ yang merupakan pakem berita jurnalistik. Sebagian besar mengambil porsi pada "what" dan "who", yaitu apa yang dikatakan atau dilakukan aktor pada berita tersebut. Pada berita dengan topik penanganan banjir, berita lebih menyorot kegiatan Anies sebagai Gubernur DKI Jakarta dan jajarannya dalam mengatasi banjir. Pada topik elektabilitas Anies yang turun karena banjir, berita menyorot pada respon beberapa politisi partai tentang hasil survei.

Komponen ketiga, yaitu struktur tematik. Berita terkait aktivitas Anies yang melakukan penanganan banjir disajikan detail dengan menunjukkan aktivitas di lokasi. Penggambaran yang dilakukan wartawan sebatas didapatkan dari akun media sosial Anies, bukan pengamatan langsung di lapangan. Saat ini, wartawan media online kerap menyajikan berita dari sumber mana pun yang dinilai kredibel. Sumber yang dirujuk Detik.com adalah akun media sosial resmi Anies Baswedan dan Dinas SDA DKI Jakarta. Sumber yang dirujuk dapat dipertanggungjawabkan, namun wartawan tidak berupaya mengambil sisi lain sebuah fakta karena hanya menampilkan satu sisi. Hal ini memperlihatkan ciri khas media online yang mengandalkan kecepatan (Margianto \& Syaefullah, 2012), sehingga informasi yang didapatkan dari sumber manapun yang kredibel langsung dikemas menjadi berita. Dari segi penyampaian berita, wartawan menyampaikannya secara koheren. Argumen terhadap kalimat dilengkapi dengan kutipan langsung narasumber. Selain itu, di beberapa berita, wartawan juga menampilkan data sebagai penguat informasi, seperti data jumlah lokasi, perkembangan kondisi wilayah terdampak 
banjir, serta data survei PPI \& PRC. Di berita 4 (Tabel 1) berjudul "Survei PPI: Elektabilitas Anies Baswedan Terjun Bebas karena Banjir", wartawan berupaya menyandingkan data hasil survei PPI \& PRC dengan hasil survei Indo Barometer pada Januari 2020. Pada berita 2 (Tabel 1), setelah menjabarkan kronologis warganet yang menyerbu tweet Anies, wartawan kemudian menyuguhkan kalimat yang berisi kegiatan Anies sedang meninjau lokasi terdampak banjir yang diambil dari story Instagram pribadinya. Dalam hal ini, wartawan berupaya memberikan klarifikasi untuk membuat berita menjadi berimbang. Dalam menyajikan berita terkait Anies, Detik.com kerap menampilkan kalimat sebagai penjelas atau klarifikasi atas persoalan utama yang diangkat. Pada penelitian Adzhani \& Ginting (2018), Detik.com menambahkan kalimat di akhir artikel yang seolah-olah mengklarifikasi bahwa dugaan terhadap Anies yang melanggar hukum melalui pidatonya yang menggunakan kata "pribumi" adalah tidak pasti kebenarannya.

Komponen keempat, struktur retoris, dilihat dari pilihan kata yang digunakan wartawan dalam menyampaikan berita. Dalam topik penanganan banjir, wartawan cenderung membahasakan informasi yang didapat dengan kalimat bertendensi netral. Tidak banyak kata-kata berkiasan yang digunakan dalam menggambarkan kejadian, seperti menggambarkan aktivitas Anies ketika meninjau genangan air. Kalimat "Anies tampak mengobrol dengan seorang petugas yang menyedot genangan air" memperlihatkan Anies mau mendengarkan suara dari 'bawah' dalam menangani masalah. Pencantuman tagar \#ResponCepatJkt dan \#OperasiSiagaJakarta di beberapa berita yang bersumber dari akun media sosial Anies menegaskan upaya Pemprov DKI dalam mengatasi banjir. Pada berita 3 (Tabel 1) yang berjudul "Usai Cek Genangan di Cempaka Putih, Anies Tinjau Pintu Air Serdang" ditulis penampilan yang dikenakan Anies secara detail ketika meninjau pintu air. Kalimat "Anies yang mengenakan sepatu bot oranye" menandakan warna identitas DKI Jakarta. Pada berita yang sama kalimat 8 tertulis "kendaraan bermotor menurunkan kecepatannya" untuk menggambarkan ketinggian banjir yang cukup dalam.

Pada berita 8 (Tabel 1) berjudul "Anies Baswedan Ungkap Penanganan Banjir Jakarta 23 Februari” terdapat kalimat “...Sebagian besar wilayah yang terdampak banjir dan genangan kemarin dipastikan telah surut." Kalimat tersebut bermakna Anies menjamin lokasi terdampak banjir dimaksud telah surut. Terlihat keterbatasan wartawan yang tidak melakukan verifikasi langsung kondisi tersebut karena hanya mengambil sumber dari Instagram Anies. Sedangkan kata-kata di berita 4 (Tabel 1) memperlihatkan ketidakberpihakan hasil survei PPI \& PRC kepada Anies. Kalimat yang berisi komentar Direktur Eksekutif PPI, Adi Prayitno “...terpaan banjir dari awal Januari sampai sekarang itu efektif membuat elektabilitas Anies terjun bebas" dan pada kalimat "Banjir, menurutnya, yang sukses menurunkan elektabilitas Anies tanpa perlu dibully" menegaskan keberpihakan tersebut. Sementara, kalimat ""Hanya banjir yang kalahkan Anies, bukan formula e, lem aibon atau buser, itu menunjukan semakin Anies dibully dikritik, Anies semakin mendapatkan simpati..." yang dikutip dari pernyataan Adi Prayitno menyiratkan posisi Anies selama ini dapat bertahan karena mendapat banyak simpati atas kritikan yang menimpanya.

Pada isi berita 6 (Tabel 1) berjudul "Elektabilitas Anies Disebut Turun Gegara Banjir, PDIP DKI: Realistis Itu Betul" dan berita 7 (Tabel 1) "Gerindra DKI Bela Anies soal Banjir Jakarta: Itu Masalah Rumit dan Kompleks" memperlihatkan sikap masing-masing partai terhadap kinerja Anies. Pada berita 6 (Tabel 1) kalimat 5 dituliskan "Gembong mengatakan Anies tidak melakukan apa-apa dalam menangani permasalahan banjir di Jakarta" disertai kutipan pada kalimat 7 "Nggak (ada kerjanya), soal banjir Anies itu nggak ngapa-ngapain gitu 
loh..." menekankan kinerja Anies yang dinilai buruk oleh PDIP. Menurut Ketua Fraksi PDIP DPRD DKI Gembong Warsono, memang sudah sepantasnya elektabilitas Anies turun karena banjir. Pernyataan ini memperlihatkan PDIP sebagai pihak oposisi Anies. Pada berita 7 (Tabel 1), Anggota DPRD DKI Jakarta Fraksi Gerindra, Syarief membela Anies karena menurutnya persoalan banjir rumit dan kompleks. Pada kalimat 7 tertulis "Syarief menilai pekerjaan Anies dalam mengatasi banjir ini lebih baik. Sebab, menurut Syarief beberapa kali banjir di Jakarta cepat surut genangannya tidak seperti banjir tahun lalu." Dukungan Gerindra terlontar karena merupakan partai pengusung Anies.

Dari analisis pada delapan berita Detik.com, dapat dilihat pemberitaan Detik.com bersifat netral. Pemberitaan Detik.com mencoba menggunakan jurnalisme berimbang. Dalam beberapa berita, wartawan Detik.com memberikan kalimat klarifikasi atau penjelasan dari pihak yang berseberangan. Namun, seperti kebanyakan media online, Detik.com masih mengandalkan penyajian berita yang tidak mengambil sumber asli (bersumber dari media sosial). Hal ini dapat memengaruhi keakuratan penyajian berita, karena akun media sosial tokoh atau organisasi memiliki tujuan pencapaian citra tersendiri.

Dari framing Detik.com pada sosok Anies, peneliti menemukan sosok Anies memiliki konsep personal branding Montoya (Wilson, 2003), yaitu the law of leadership (kepemimpinan), the law of personality (kepribadian), the law of distinctiveness (keunikan), the law of visibility (visibilitas), dan the law of unity (kesatuan), namun tidak memiliki the law of specialization (spesialisasi). Anies digambarkan sebagai pemimpin daerah yang cepat tanggap menangani banjir. Pada hari terjadinya banjir (23 Februari 2020), pada hari itu pula lah Anies langsung meninjau lokasi terdampak banjir. Dalam berita 8 (Tabel 1) juga terlihat bagaimana Anies menggunakan wewenangnya untuk mengintruksikan jaja- rannya, yaitu Dinas SDA, BPBD, Dinas Sosial, Dinas Penanggulangan Kebakaran dan Penyelamatan hingga PPSU Kelurahan untuk mengatasi banjir sesuai tugas dan fungsinya masing-masing. Kepribadian Anies disinggung dalam berita 5 (Tabel 1) "Elektabilitas Anies Disebut Turun karena Banjir, PKS: Harapan Publik Tinggi”, di mana Politikus PKS, Indra menilai publik berharap tinggi pada sosokAnies. Indra melihatAnies kerap dipersalahkan ketika banjir terjadi, bahkan di luar Jakarta yang bukan merupakan wilayahnya. Keunikan Anies sebagai tokoh publik dilihat dari penggunaan tagar di unggahan media sosial Anies yang menunjukkan ekspresi dirinya dalam menanggapi suatu hal. Tagar \#WajahBaruJakarta di tweet Anies seolah menggambarkan ekspresi kegembiraannya sudah membangun Jakarta menjadi bagus, walaupun akhirnya dibalas dengan sindiran oleh warganet. Penggunaan tagar \#ResponCepatJkt dan \#OperasiSiagaJakarta digunakan Anies untuk memperlihatkan respon cepat Pemprov DKI dalam mengatasi banjir.

Visibilitas Anies sangat terlihat melalui unggahan kegiatannya di media sosial sebagai Gubernur DKI Jakarta. Unggahan Anies kerap dijadikan sumber berita oleh pewarta serta dapat memancing interaksi dengan masyarakat, baik yang bersifat positif atau negatif. Seperti pada berita 2 (Tabel 1), di mana tweet-nya disindir warganet dan menjadi trending topic. Konsep kesatuan yang dimiliki Anies ditunjukkan pada berita 1 dan 2 (Tabel 1), di mana dituliskan Anies sedang mengobrol dengan petugas yang menyedot genangan air di Cempaka Putih Barat. Penggambaran interaksi antara Anies dan petugas memperlihatkan sosoknya sebagai pemimpin yang mau mendengar persoalan dari 'bawah' dalam menangani masalah. Sebagai seorang pemimpin daerah, Anies dibingkai sebagai sosok yang tidak memiliki spesialisasi karena belum bisa menjalankan program penanganan banjir. Hal ini terlontar dari Ketua Fraksi PDIP DPRD DKI pada berita 6 (Tabel 1). 
Detik.com menggambarkan Anies Baswedan sebagai sosok pemimpin yang cepat tanggap serta pemimpin yang mau turun langsung ke lapangan dalam menangani banjir. Walaupun terdapat berita yang menilai Anies belum mampu menjalankan program penanganan banjir, namun di berita selanjutnya memperlihatkan kinerja Anies lebih baik dibanding penanganan banjir tahun lalu. Hal ini sesuai karakteristik media online yang memunculkan sebuah topik utama menjadi beberapa berita, yang membuat keberimbangan biasanya tidak muncul pada berita pertama, tapi pada berita kedua, ketiga, dan selanjutnya (Margianto \& Syaefullah, 2012). Dalam berbagai permasalahan di Jakarta, Detik. com membingkai publik memiliki ekspektasi tinggi kinerja Anies. Hal ini tidak terlepas dari begitu dikenalnya Anies oleh publik lewat pemberitaan maupun unggahannya di media sosial. Anies aktif menggunakan media sosial untuk membagikan aktivitasnya. Keaktifan Anies dalam media sosial sudah dilakukan sejak mendirikan program "Indonesia Mengajar". Penelitian Ramadhan et al., (2016) menunjukkan personal branding Anies Baswedan melalui Facebook dan Twitter bagus. Penyajian diri Anies di media sosial dinilai berbeda, sehingga sebagian besar responden mengetahui tentang Anies dan program pendidikan yang dijalankan melalui media sosial.

\section{Framing Sosok Gubernur DKI Jakarta di Kompas.com}

Dari tujuh berita di Kompas.com pada Tabel 1, sebanyak tiga berita bertema kritik program penanganan banjir Anies Baswedan, dua berita tentang ramainya sindiran terhadap Anies di Twitter, satu berita tentang elektabilitas Anies yang turun menurut hasil survei PPI dan PRC, dan satu berita tentang penanganan banjir oleh Anies. Komponen pertama yang dianalisis adalah struktur sintaksis. Sebagian besar berita (enam berita) ditulis mengikuti struktur piramida terbalik, di mana wartawan menuliskan informasi paling penting di bagian atas tulisan, seterusnya hingga akhir sebagai informasi pendukung.
Berbeda pada berita 6 (Tabel 1) yang berjudul "Minta Anies Tak "Tenggelamkan" Kelapa Gading, Warga Tuntut Dana Banjir Dikembalikan", di mana wartawan mengikuti skema penulisan feature. Berita ini dimulai dengan kutipan warga Kelapa Gading yang mengeluh soal banjir yang berulang kali terjadi di perumahannya. Tidak seperti enam berita lainnya yang menggunakan lead berupa kalimat tidak langsung berisi inti persoalan, persoalan utama yang diangkat pada berita tersebut adalah keluhan warga Kelapa Gading tentang banjir di wilayahnya. Terdapat tiga keluhan yang dituliskan, yaitu bantuan alat penanganan banjir, operasionalisasi alat berat untuk antisipasi banjir, serta pengurangan anggaran banjir. Berita tersebut ditutup dengan tanggapan Anies terhadap keluhan warga dan spekulasi terjadinya banjir. Sebagian besar berita yang dianalisis menggunakan informasi pendukung yang sama sebagai penutup, yaitu lokasi terdampak banjir beserta ketinggian air, serta imbas banjir.

Beberapa judul berita pada Tabel 1 bertendensi netral, namun beberapa judul memberi penekanan bahwa Anies sedang dikritik berbagai pihak terkait banjir, yaitu pada judul berita 3 "Kritik Anies, Ketua DPRD DKI Nilai SOP Penanganan Banjir Tidak Jelas", berita 5 "Anies Disindir Warganet Saat Banjir, Politisi PKS: Itu Risiko, Tidak Usah Baper", berita 6, dan berita 7 "PSI DKI: Anies 2,5 Tahun Jadi Gubernur, Program Antisipasi Banjir Jalan di Tempat". Judul berita 5 (Tabel 1) bertendensi negatif, namun isinya cenderung netral. Inti berita 5 adalah dukungan Anggota Fraksi PKS DPRD DKI Jakarta Abdul Azis bagi Anies untuk fokus bekerja menangani banjir. Azis memaklumi Jakarta menjadi langganan banjir, apalagi tingginya curah hujan saat itu. Namun, Azis meminta Anies untuk lebih serius mengatasi banjir dengan mengevaluasi dan merevitalisasi infrastuktur penanganan banjir. Sementara pada judul berita 6 (Tabel 1) menarik perhatian pembaca, namun isi berita menunjukkan kalimat pada judul bersumber dari dua orang berbeda, sehingga wartawan seperti menarik kesimpulan sendiri. 
Latar belakang informasi ada yang ditampilkan di tengah paragraf sebagai transisi antara permasalahan utama dengan penjelasan serta di paragraf terakhir sebagai informasi pendukung. Pada berita 6 (Tabel 1), terdapat beberapa latar belakang informasi yang menjadi jembatan antara beberapa topik yang dikemukakan. Latar belakang informasi 1 adalah frekuensi banjir di awal tahun yang mengakibatkan Kelapa Gading banjir. Latar belakang informasi 2, yaitu penanganan banjir di Kelapa Gading yang dilakukan Pemprov DKI era BTP tidak dilakukan pemprov saat ini. Hal inilah yang membuat warga berspekulasi mengapa wilayahnya sering terkena banjir dan lama surut. Latar belakang informasi 3 adalah pengurangan alokasi anggaran banjir sehingga disinyalir penanganan banjir tidak maksimal.

Dalam penyajian berita, wartawan Kompas. com menampilkan kutipan narasumber untuk memperkaya informasi. Hanya di berita 1 (Tabel 1) berjudul "Jakarta Banjir, Netizen Serbu Tagar \#WajahBaruJakarta untuk Sindir Anies" yang tidak menampilkan kutipan hasil wawancara dengan narasumber, semua sumber diambil dari Twitter. Narasumber pada berita-berita bertemakan hasil survei PPI \& PRC mewakili pihak yang berkepentingan, seperti Direktur Eksekutif PPI, Politisi PKS sebagai partai pendukung Anies, dan Anggota Fraksi Partai Solidaritas Indonesia (PSI) DPRD DKI Jakarta sebagai partai oposisi Anies. Pada berita 6 (Tabel 1) tentang keluhan warga Kelapa Gading yang kebanjiran, wartawan Kompas.com juga menambahkan sumber dari Kepala Dinas (Kadis) SDA DKI Jakarta dan Anies untuk mengonfirmasi spekulasi penyebab banjir dan pengurangan anggaran banjir.

Komponen kedua adalah struktur skrip. Dari ketujuh berita di Kompas.com, hampir semuanya memuat unsur $5 \mathrm{~W}+1 \mathrm{H}$. Namun, pada berita 4 (Tabel 1) yang berjudul "Banjir Kembali Landa Jakarta, Anies Kerahkan Tim Gabungan" hanya memuat $4 \mathrm{~W}$ (what, when, where, who) $+1 \mathrm{H}$. Unsur "why" tidak ditampilkan, berita dikemas seperti laporan tindakan penanganan banjir yang dilakukan Anies beserta jajarannya.
Komponen ketiga, yaitu struktur tematik. Pada berita 1 (Tabel 1) wartawan menampilkan tagar \#WajahBaruJakarta yang menjadi trending topic di Twitter. Berita dikemas dengan menampilkan data jumlah tweet dan beberapa tweet yang menggunakan tagar tersebut untuk menyindir tweet Anies sehari sebelumnya. Wartawan menampilkan subjudul "Di Mana Anies Hari Ini?” yang seolah mempertanyakan keberadaan Anies ketika banjir kembali terjadi dan ramainya Twitter memperbincangkan Anies. Subjudul tersebut didukung dengan informasi kegiatan Anies meninjau pintu air dan genangan banjir yang bersumber dari story Instagram-nya. Sementara pada berita 3 (Tabel 1) berisi kritik Ketua DPRD DKI Jakarta terhadap kinerja Anies menangani banjir dengan membandingkan kinerja pendahulunya, BTP. Perbandingan kinerja kerap digunakan dalam berita untuk menunjukkan kualitas kinerja seorang pejabat. Berita ini juga mengemukakan soal Standard Operating Procedures (SOP) banjir yang tidak jelas dan kesalahan Anies dalam menempatkan orang di posisi Kadis SDA.

Pada berita 6 (Tabel 1), cara wartawan menyampaikan berita tidak memberikan penekanan pada inti persoalan. Persoalan yang dikemukakan lebih dari satu, yaitu ketiadaan bantuan peralatan penanganan banjir di Kelapa Gading, ketidaksiagaan pompa dan alat-alat berat, spekulasi warga tentang penyebab banjir, dan pengurangan anggaran banjir. Di penutup ditampilkan tanggapan Anies mengenai tudingan warga, pembaca tidak dapat langsung memahami tudingan mana yang dimaksud. Proporsi berita 6 sebagian besar berisi keluhan warga tentang persoalan banjir. Kadis SDA dan Anies ditampilkan dalam berita, namun dengan porsi sedikit untuk mengklarifikasi. Dari ketujuh berita Kompas.com, terdapat dua berita yang bersumber dari akun media sosial Anies. Sementara berita lainnya merupakan reportase lapangan. Argumen Anies secara langsung hanya didapatkan wartawan pada berita 6 , namun terlihat upaya wartawan untuk menghadirkan keberimbangan. 
Pada komponen keempat, yaitu struktur retoris, peneliti melihat pilihan kata dalam menekankan arti tertentu pada pembaca. Pada berita 1 (Tabel 1) tertulis "Di mana Anies hari ini? Di saat sejumlah wilayah terendam banjir pada hari ini, Gubernur DKI Jakarta Anies Baswedan membagikan kegiatannya meninjau lokasi banjir dan pintu air melalui fitur Instagram Story pada akun resmi Instagram,@aniesbaswedan”. Pada kalimat tersebut, wartawan memilih menggunakan kata "Anies Baswedan membagikan kegiatannya meninjau", dibanding langsung menggunakan kata "meninjau". Hal ini bermakna bahwa di saat warganet ramai memperbincangkan dirinya di Twitter, Anies malah membagikan kegiatannya di story Instagram. Berbeda jika wartawan menggunakan kata "meninjau" langsung yang menekankan bahwa di saat warganet ramai memperbincangkan dirinya di Twitter, Anies telah bertindak mengatasi banjir dengan meninjau lokasi banjir. Pada berita 2 (Tabel 1) berjudul "Survei: Masalah Banjir DKI jadi Penyebab Elektabilitas Anies Anjlok" terdapat beberapa pilihan kata yang memberi penekanan tertentu. Di kalimat 2, wartawan menggunakan kata "mantan pembantu Jokowi" untuk menggambarkan Anies. Pilihan kata ini memperlihatkan Anies dulunya bekerja untuk Jokowi, namun kini di pihak oposisi. Selain itu, pada kalimat 18 dituliskan "Hanya banjir yang mengalahkan Anies," memberi penekanan elektabilitas Anies turun karena murni kinerjanya tidak baik, bukan karena faktor eksternal.

Pada berita 3 (Tabel 1) kalimat 14 tertulis "bukan jagonya" yang mengacu pada sosok Kadis SDA. Kata ini memberikan makna orang yang dipilih Anies bukan orang yang kompeten sebagai Kadis SDA. Pada berita 4 (Tabel 1) tertulis "Anies Baswedan mengaku telah mengerahkan sejumlah tim gabungan..." (kalimat 1) dan "Anies mengklaim bahwa Dinas SDA langsung memonitor..." (kalimat 5). Dua kalimat ini bermakna bahwa pernyataan tersebut pengakuan sepihak Anies yang belum ditelusuri kebenarannya oleh wartawan. Wartawan Kompas.com memang mengambil sumber dari unggahan di Instagram Anies, bukan reportase ke lapangan.
Pada berita 5 (Tabel 1), wartawan mengutip penuturan Abdul Azis "...tidak usah ditanggapi dengan baper lah biasa saja”. Kutipan ini mengacu pada Anies yang dinilainya tidak perlu baper saat disindir warganet di Twitter. Penuturan Abdul Azis juga mengesankan Anies sosok yang baper ketika dikritik orang lain. Pada berita 6 (Tabel 1) juga terdapat beberapa penekanan pada pilihan kata yang digunakan. Pada kalimat 2 tertulis "Dessy begitu menggebu-gebu meluapkan kegeramannya.." yang menekankan warga sangat kesal seolah hilang kesabarannya dengan banjir yang sering terjadi. Dessy, salah satu warga yang diwawancara juga membandingkan antisipasi banjir Pemprov DKI pada era Anies dan BTP menekankan bahwa Pemprov DKI era Anies tidak memprioritaskan masalah banjir di wilayahnya. Pada kalimat 33, warga lainnya, Ani mengatakan "Apa Kelapa Gading ini mau ditenggelamkan?" Ungkapan ini bernada sinisme yang bermakna ketidakpuasan terhadap kinerja Pemprov DKI dalam menangani banjir dan semakin menegaskan kalimat-kalimat sebelumnya bahwa Pemprov DKI belum bertindak menangani banjir di Kelapa Gading. Atas semua keluhan yang disampaikan warga Kelapa Gading di dalam berita tersebut, pada kalimat penutup wartawan Kompas.com menuliskan "Anies pun tidak mau berkomentar lebih banyak mengenai tudingan tersebut". Anies berucap "Bukan hanya tidak benar, itu mengarang,..” Kalimat penutup tersebut seperti meyakinkan pembaca bahwa Anies seolah tidak peduli dengan persoalan banjir di Kelapa Gading. Kalimat tersebut juga menimbulkan pertanyaan yang dimaksud Anies tidak benar, apakah tudingan spekulasi penyebab banjir atau pemotongan anggaran penanganan banjir.

Pada berita 7 (Tabel 1) tertulis komentar Justin, Anggota Fraksi PSI DPRD DKI Jakarta "Pak Gubernur tidak punya alasan untuk menyalahkan hujan di Bogor dan tidak bisa melempar masalah ke pemerintah pusat..." dan "Sayangnya, Pak Gubernur tidak memiliki kemauan dan keberanian untuk mengatasi banjir." Dua kalimat 
ini mengesankan Anies sosok yang suka melempar masalah, serta pemimpin yang tidak memiliki kemauan dan keberanian mengatasi banjir.

Berdasarkan konsep personal branding yang dikemukakan Montoya (Wilson, 2003), dari analisis terhadap tujuh berita di Kompas. com, sosok Anies Baswedan memiliki visibilitas karena mampu memanfaatkan peluang dengan mempromosikan kinerjanya melalui media sosial. Pada berita 1 (Tabel 1), Anies mengunggah foto Jakarta yang indah dengan tagar \#WajahBaruJakarta menunjukkan hasil kinerjanya membangun Jakarta, walaupun unggahannya tersebut disindir ketika Jakarta kembali dilanda banjir keesokan harinya. Di dalam berita tersebut, diperlihatkan Anies membagikan kegiatannya meninjau banjir melalui story Instagram-nya. Pada berita 4 (Tabel 1) berjudul "Banjir Kembali Landa Jakarta, Anies Kerahkan Tim Gabungan" bersumber dari unggahan Instagram Anies. Di unggahannya tersebut, Anies menceritakan bagaimana pengerahan timnya untuk mengatasi banjir dan menginformasikan kondisi terkini banjir di Jakarta. Keunikan sosok Anies yang ditampilkan dalam pembingkaian Kompas.com adalah Anies dikenal sering dikritik dan terkena perundungan oleh beberapa pihak. Hal ini dipertegas oleh komentar Direktur Eksekutif PPI di berita 2 (Tabel 1) yang mengatakan pada hasil survei sebelumnya semakin banyak Anies dikritik, publik semakin simpatik. Berbeda dengan persoalan banjir, elektabilitas Anies turun dengan sendirinya. Hal serupa juga terdapat di berita 5 (Tabel 1) yang memuat komentar Abdul Azis bahwa risiko menjadi pimpinan harus siap dikritik dan tidak perlu menanggapinya secara berlebihan. Tanggapan Abdul Azis tersebut memperlihatkan sosok Anies yang mudah baper ketika dikritik. Pada berita 2 (Tabel 1) digambarkan dengan kritikan dan perundungan tersebut membuat elektabilitas Anies menanjak. Kapabilitas Anies dibingkai tidak memiliki spesialisasi karena tidak mampu mengatasi banjir di
Jakarta. Anies tidak memiliki SOP penanganan banjir yang jelas serta salah memfungsikan pompa (berita 3, Tabel 1). Kepemimpinan Anies juga disorot karena dianggap tidak mampu memecahkan masalah banjir di Jakarta. Anies dinilai salah menempatkan orang di posisi vital penanganan banjir, yaitu Kadis SDA. Di satu sisi, pada berita 4 (Tabel 1), Anies dibingkai telah menjalankan otoritasnya sebagai gubernur untuk mengerahkan tim gabungan menangani banjir. Berita tersebut dikemas menggunakan pilihan-pilihan kata yang agak menyudutkan Anies seperti "Anies mengaku..." dan "Anies mengklaim...", seperti pengakuan dan klaim sepihak Anies.

Dari sisi kepribadian, Anies dinilai sebagai pemimpin yang suka melempar masalah ketika banjir melanda. Sebagai pemimpin, Anies dianggap tidak mau mengambil risiko. Hal ini tergambar dalam ungkapan Anggota Fraksi PSI DPRD DKI Jakarta di berita 7 (Tabel 1). Anies juga dibingkai sebagai pemimpin yang tidak mampu menyatukan aspirasi warganya yang terkena banjir (berita 6, Tabel 1). Kegigihan tidak ada dalam diri Anies karena di dalam berita 7 dikatakan Anies tidak memiliki keberanian dan kemauan dalam mengatasi banjir.

Dari keseluruhan pembingkaian, Kompas. com membingkai sosok Anies Baswedan secara negatif. Anies dibingkai tidak memiliki kapabilitas sehingga banjir masih terjadi di Jakarta. Ketidakmampuan Anies dalam menangani banjir di Jakarta ditunjukkan dengan SOP penanganan banjir yang tidak jelas, kesalahan memfungsikan infrastruktur pencegahan banjir, serta penempatan pejabat yang tidak mumpuni di dalam timnya. Dalam menyikapi persoalan banjir, Anies dibingkai sebagai pemimpin yang suka melempar masalah, alih-alih menyelesaikan masalah. Kritikan yang diterima Anies disikapi dengan baper, sehingga Anies kerap dicitrakan menjadi sasaran politik. Citra ini lekat dengan Anies, sehingga menimbulkan simpati dari masyarakat dan beberapa kali memengaruhi elektabilitasnya dalam beberapa survei politik. 
Pembingkaian ini sejalan dengan hasil penelitian Pinontoan \& Wahid (2020) yang juga mengangkat pembingkaian pemberitaan banjir Jakarta. Hasilnya menunjukkan Kompas.com mengonstruksi peran pemerintah daerah dalam menangani banjir Jakarta Januari 2020 cenderung pada pemberitaan dengan frame-frame negatif, yaitu menuntut, mempertanyakan, dan menggugat ketidakberdayaan pemerintah daerah dalam menangani banjir Jakarta Januari 2020. Hal ini memperlihatkan posisi Kompas. com yang kritis terhadap pemerintah daerah DKI Jakarta di bawah kepemimpinan Anies Baswedan dan pembingkaian yang dilakukan cenderung negatif. Berbeda dengan pembingkaian yang dilakukan Kompas.com terhadap sosok Gubernur DKI Jakarta sebelumnya, BTP. Kompas.com membingkai kinerja BTP dalam menangani banjir dinilai lebih baik dibanding Anies. Pada penelitian Supardi (2017) juga menunjukkan pembingkaian Kompas.com terhadap sosok BTP sebagai pemimpin baik yang membela kepentingan publik dalam isu reklamasi dan kerap menjadi sasaran serangan politik.

Dikaitkan dengan teori kepemimpinan, Detik.com membingkai kepemimpinan Anies dalam menangani banjir Jakarta menggunakan pendekatan kepemimpinan transformasional. Anies dibingkai sebagai pemimpin yang mampu memecahkan masalah banjir dengan kesigapannya menangani banjir yang kembali terjadi di Jakarta (faktor stimulasi intelektual). Anies langsung turun lapangan dan berkoordinasi dengan timnya untuk mengatasi banjir. Kinerja Anies dalam menangani banjir dinilai lebih baik dibanding tahun lalu dilihat dari kecepatan surutnya ketinggian air. Walaupun Jakarta kembali dilanda banjir, pengikut Anies memandang Anies sebagai pemimpin karismatik, di mana pengikut menyematkan harapan besar padanya. Banjir pada awal tahun 2020 merupakan faktor alam, bukan semata dikarenakan ketidakmampuan Anies. Pembingkaian Anies juga dilihat dari pertimbangan individualnya dalam mengoordinasikan jajarannya untuk segera menangani banjir yang kembali terjadi.
Kompas.com membingkai kapabilitas dan kepemimpinan Anies menggunakan pendekatan kepemimpinan transaksional. Anies dibingkai tidak mampu memenuhi janjinya kepada warga Jakarta untuk menyelesaikan banjir sebagai salah satu program prioritasnya ketika pemilihan Gubernur DKI Jakarta. Program penanganan banjir yang dijalankan selama ini dinilai tidak efektif. Kekecewaan warga kinerja Anies tersebut diperlihatkan dengan hasil survei PPI dan PRC, di mana elektabilitas Anies turun karena persoalan banjir. Perbedaan pembingkaian ini memperlihatkan bagaimana cara masing-masing media melihat sebuah realitas, yaitu penanganan banjir yang dilakukan Anies Baswedan sebagai Gubernur DKI Jakarta. Dengan pembingkaian yang dilakukan Detik.com dan Kompas.com terhadap kapabilitas dan kepemimpinan Anies Baswedan dalam menangani banjir Jakarta memengaruhi persepsi publik terhadap sosok Anies.

Penelitian ini memberi kontribusi usulan kebijakan bagi pengelola media online agar melakukan keberimbangan dalam memberitakan tokoh publik. Keberimbangan dapat dilakukan dengan memberikan ruang untuk memberikan klarifikasi terhadap topik yang diangkat. Fenomena jurnalisme, terutama media online, banyak wartawan membuat sebuah berita hanya mengandalkan sumber dari media sosial tokoh atau organisasi tertentu, perlu diperkaya dari sumber lain sebagai verifikasi lapangan. Hal ini untuk menghindari berbagai asumsi terkait persoalan yang diangkat dan demi keakuratan berita. Informasi yang berimbang, pembaca dapat memperoleh gambaran utuh dalam menilai performa tokoh secara keseluruhan.

\section{Simpulan}

Dari pembingkaian berita yang dilakukan Detik.com dan Kompas.com terhadap kapabilitas dan kepemimpinan Gubernur DKI Jakarta, Anies Baswedan dalam menangani banjir, ditemukan adanya perbedaan pembingkaian dari kedua media online ini. Di tengah persoalan banjir yang di- 
hadapi warga Jakarta yang juga menyorot kinerja Gubernur DKI Jakarta, Detik.com membingkainya dari sisi positif. Upaya menghadirkan berita berimbang dalam satu rangkaian topik utama penanganan banjir dilakukan Detik.com. Fakta yang ditampilkan tidak berupaya menyudutkan atau menggugat Anies, namun seakan mengklarifikasi dengan tindakan yang dilakukan Anies dalam menangani banjir. Detik.com membingkai kapabilitas dan kepemimpinan Anies dengan pendekatan kepemimpinan transformasional. Sosok Anies dibingkai sebagai seorang pemimpin yang memiliki kapabilitas dan kepemimpinan yang baik dalam menangani banjir dibingkai dengan kecepatan dalam merespon banjir yang sedang melanda. Visibilitas Anies baik di mata publik yang terlihat dalam setiap unggahannya di media sosial. Hal ini menunjukkan transparansi publik atas serangkaian kerja yang telah dilakukan Anies dalam menangani banjir di Jakarta.

Kompas.com membingkai kapabilitas dan kepemimpinan Anies dengan frame negatif. Pembingkaian Kompas.com lebih pada pendekatan kepemimpinan transaksional. Banjir yang terjadi berulang kali di awal tahun 2020 memperlihatkan ketidakmampuan Anies Baswedan sebagai Gubernur DKI Jakarta dalam menjalankan program penanganan banjir. Janji politik Anies kepada warganya untuk menyelesaikan permasalahan banjir dianggap tidak dapat dipenuhi. Kompas.com berupaya membandingkan kapabilitas Anies dengan pendahulunya yaitu Basuki Tjahya Purnama (BTP), dalam penanganan banjir yang dianggap lebih baik. Hal ini memperlihatkan posisi Kompas.com yang kerap mengritisi pemerintahan DKI Jakarta di era Anies. Di sisi lain, Kompas.com membingkai Anies sebagai sosok pemimpin yang tidak siap menerima kritikan dan membalikkannya sebagai citra yang melekat pada dirinya, yaitu selalu dijadikan sasaran politik.
Kontribusi penelitian ini berupa rekomendasi kepada pengelola media online agar mengedepankan unsur keberimbangan dan kecepatan dalam pemberitaannya. Khususnya dalam membingkai kapabilitas dan kepemimpinan tokoh publik, keberimbangan sumber informasi dapat memengaruhi persepsi publik terhadap performa tokoh tertentu.

\section{Ucapan Terimakasih}

Terima kasih kepada Prof. Ibnu Hamad dan Dr. Udi Rusadi, M.S. atas bantuannya untuk penelitian ini.

\section{Daftar Pustaka}

Adhiarso, D. S., Utari, P., \& Slamet, Y. (2017). Pemberitaan Hoax di Media Online Ditinjau dari Konstruksi Berita dan Respons Netizen. Jurnal Ilmu Komunikasi, 15(3), 215225. Diakses dari http://jurnal.upnyk.ac.id/ index.php/komunikasi/article/view/2173 Adzhani, N., \& Ginting, R. (2018). Framing Analysis of Anies Baswedanrs Pribumi Speech in detik.com and viva. co.id. 260(Icomacs), 206-209. https:// doi.org/10.2991/icomacs-18.2018.51

Astuti, M. (2016). Konstruksi Sosial Media Terhadap Kekuatan Personal Branding Tri Rismaharini dalam Proses Komunikasi Politik Kontemporer (Analisis Framing Pemberitaan Di Media Online Republika.co.id dan Tempo.com). Jurnal Dakwah Dan Komunikasi, 1(1), 1-20.

Azhar, A. A., \& Pekuwali, D. (2018). Framing Analysis of Edy Rahmayadi's News on MedanBisnisdaily.com. Budapest International Research and Critics Institute (BIRCI-Journal): Humanities and Social Sciences, 1(3), 137-143. https://doi.org/10.33258/birci.v1i3.37

Bass, B. M. (1985). Leadership: Good, Better, Best. Organizational Dynamics, 13(3), 26-40. https://doi. org/10.1016/0090-2616(85)90028-2 
Burgers, C., Konijn, E. A., \& Steen, G. J. (2016). Figurative Framing: Shaping Public Discourse Through Metaphor, Hyperbole, and Irony. Communcation Theory, 26(4), 410 430. https://doi.org/10.1111/comt.12096

Eriyanto. (2002). Analisis Framing: Konstruksi, Ideologi, dan Politik Media (1st Edisi). Yogyakarta: LKiS.

Gardner, W. L. (2003). Perceptions of leader charisma, effectiveness, and integrity: Effects of Exemplification, Delivery, and Ethical Reputation. Management Communication Quarterly, 16(4), 502-527. https://doi.org/10.1177/0893318903251324

Hamad, I. (2007). Lebih Dekat dengan Analisis Wacana. Mediator: Jurnal Komunikasi, $\quad 8(2), \quad 325-344 . \quad$ https://doi. org/10.29313/mediator.v8i2.1252

Kotler, P., \& Keller, K. L. (2016). Marketing Management. In Marketing Management (15th Globa). USA: Pearson Education Limited. https://doi.org/10.4324/9780203357262

Lecheler, S., \& De Vreese, C. H. (2012). News framing and public opinion: A mediation analysis of framing effects on political attitudes. Journalism and Mass Communication Quarterly, 89(2), 185-204. https:// doi.org/10.1177/1077699011430064

Lee, A. M., Lewis, S. C., \& Powers, M. (2014). Audience Clicks and News Placement: A Study of Time-Lagged Influence in Online Journalism. Communication Research, 41(4), 505-530. https:// doi.org/10.1177/0093650212467031

Lestari, R. D. (2017). Quality News dan Popular News sebagai Trens Pemberitaan Media Online (Studi Deskriptif Kualitatif Trend Pemberitaan Quality News dan Popular News pada Media Online Nasional di Indonesia Periode 2016). CHANNEL: Jurnal Komunikasi, 5(1), 83-94. https://doi.org/10.12928/channel.v5i1.6355
Liu, B. F., Iles, I. A., \& Herovic, E. (2020). Leadership under Fire: How Governments Manage Crisis Communication. Communication Studies, 71(1), 128-147. https:// doi.org/10.1080/10510974.2019.1683593

Lova, C., \& Maullana, I. (2020). Sejak Awal 2020 Sudah Enam Kali Jakarta Kebanjiran, Anies Diminta Dengarkan Saran Jokowi. Kompas.com. Diambil dari https://megapolitan. kompas.com/read/2020/03/02/08404821/ sejak-awal-2020-sudah-enam-kali-jakarta-kebanjiran-anies-diminta Margianto, H. J., \& Syaefullah, A. (2012). Media Online: Pembaca, Laba, dan Etika. Aliansi Jurnalis Independen Indonesia. Diambil dari http:/www.tovima.gr/culture/article/?aid=416698 Marland, A. (2013). What is a political brand? Justin Trudeau and the theory of branding in Canadian political science. June 2013. Mastiyanto, A. (2020). Daftar Alexa Rank Website di Indonesia, Rangking Berapakah Kompasiana? Kompas.com. Diambil dari https://www.kompasiana.com/ rakyatjelata/5e4ffbe $2 \mathrm{~d} 541 \mathrm{df} 2 \mathrm{e} 352889 \mathrm{f} 2 /$ daftar-alexa-rank-website-di-indonesia-rangking-berapakah-kompasiana

Pan, Z., \& Kosicki, G. M. (1993). Framing Analysis : An Approach to News Discourse. 55-75.

Pinontoan, N. A., \& Wahid, U. (2020). Analisis Framing Pemberitaan Banjir Jakarta Januari 2020 di Harian Kompas.com dan Jawapos. com. Komuniti: Jurnal Komunikasi dan Teknologi Informasi, 12(1), 11-24. https:// doi.org/10.23917/komuniti.v12i1.9928 Ramadhan, F. A., Setyastuti, Y., \& Maulina, N. (2016). Personal Branding of Anies Baswedan Through Facebook And Twitter Account: Study Of Image Grid Analysis in Banjarmasin Society Aged 17 - 24 Years. Journal of Government and Politics, 7(3). https://doi.org/10.18196/jgp.2016.0037 
Riyantini, R., \& Sarwititi. (2018). Naskah Pidato Kenegaraan Presiden Joko Widodo dalamPerspektif Komunikasi Politik dan Pembangunan. Jurnal Ilmu Komunikasi, 16(2016), 138 146. Diakses dari http://jurnal.upnyk.ac.id/ index.php/komunikasi/article/view/2690

Scheufele, D. A., \& Tewskbury, D. (2007). Framing, Agenda Setting, and Priming: The Evolution of Three Media Effects Models. Journal of Communication, 57(1), 9-20. https:// doi.org/10.1111/j.1460-2466.2006.00326.x

Solihin, M., \& Kurnia, N. (2017). Pemaknaan Konflik Pabrik Semen Kendeng dalam Framing Media Berita Online kompas.com dan suaramerdeka.com. Jurnal Ilmu Komunikasi, 15(1), 16-27. Diakses dari http://jurnal.upnyk.ac.id/index.php/komunikasi/article/view/2151

Srisadono, W. (2018). Komunikasi Publik Calon Gubernur Provinsi Jawa Barat 2018 dalam Membangun Personal Branding Menggu- nakan Twitter. Jurnal Pustaka Komunikasi. E-ISSN 2614-8498, diakses 25/05/2019. Jurnal Pustaka Komunikasi., 1(2), 213-227. Supardi, A. (2016). Berani, Tegas, Benar: Analisis Framing Okezone.com, Mediaindonesia.com, dan Kompas.com Terhadap Ahok dalam Isu Reklamasi. Komunikatif, Jurnal Ilmiah Komunikasi, 5(2), 35-60. https://doi.org/10.33508/jk.v5i2.988 Vreese, C. H. De. (2005). News framing: Theory and typology. Information Design Journal, 13(1), 51-62. https:// doi.org/10.1075/idjdd.13.1.06vre Wilson, G. (2003). The Personal Branding Phenomenon. London: Personal Branding Press Yuzi, H. S., Afifi, S., \& Utami, Y. S. (2019). Analisis Naratif Pemberitaan Prancis Sebagai Juara Piala Dunia 2018 di Harian Kompas. Jurnal Ilmu Komunikasi, 17(1), 8594. Diakses dari http://jurnal.upnyk.ac.id/ index.php/komunikasi/article/view/3515 